Note: This is the accepted manuscript version of the journal article, which is made available for scholarly purposes only, after a 12 month embargo from 18 April 2014 to 18 April 2015 in accordance with the journal's author permissions.

The final publication is available at Springer via http://dx.doi.org/10.1007/s10460-014-9500-z

Citation: Phillips, David P. (2014) Uneven and unequal people-centered development: the case of Fair Trade and Malawi sugar producers. Agriculture and Human Values. ISSN 0889-048X (Print), 1572-8366 (Online) (In Press) (doi:10.1007/s10460-014-9500-z) 


\title{
Uneven and unequal people-centered development: the case of Fair Trade and Malawi sugar producers
}

\section{David P. Phillips}

Accepted: 28 January 2014

\begin{abstract}
This paper advances critical Fair Trade literature by exploring reasons for and lessons from uneven and unequal lived experiences of Fairtrade certification. Fieldwork was conducted in 2007 and 2008 to explore views and develop interpretations from various actors directly and indirectly participating in a Fairtrade certified sugar organization in Malawi. By exploring an embedded social and political context in a production place, and challenging assumptions and expectations of a Fair Trade community empowerment approach, research reveals intended and unintended consequences since certification. Findings propose lessons to adopt more nuanced understandings of place and context in Fair Trade approaches to facilitate more balanced community empowerment outcomes.
\end{abstract}

Keywords: Fair Trade $\cdot$ Community $\cdot$ Empowerment $\cdot$ Sugar $\cdot$ Malawi

$\begin{array}{ll}\text { Abbreviations } \\ \text { ACP } & \text { African Caribbean Pacific } \\ \text { DOP } & \text { Division of proceeds } \\ \text { EU } & \text { European Union } \\ \text { FLO } & \text { Fairtrade Labeling Organizations International } \\ \text { FSP } & \text { Fairtrade Social Premium } \\ \text { FTO } & \text { Fair Trade Organization } \\ \text { GPN } & \text { Global Production Networks } \\ \text { GVC } & \text { Global Value Chain } \\ \text { KCGL } & \text { Kasinthula Cane Growers Limited (in Malawi) }\end{array}$

D.P. Phillips

Natural Resources Institute, University of Greenwich, Medway Campus, Central Avenue, Chatham Maritime, Kent, ME4 4TB, United Kingdom 
e-mail: d.p.phillips@gre.ac.uk

\section{Author Biography}

David Phillips, $\mathrm{PhD}$, is a Research Fellow at the Natural Resources Institute, University of Greenwich. He has conducted research on fair and ethical trade, and worked in the private sector with ethically certified producer groups and supply chains. His current research and consultancy work and interests are related to sustainable sourcing initiatives, smallholder agriculture business development, and ethical trade.

\section{Acknowledgments}

I am grateful to the countless number of people in Malawi who participated in and supported this research. This includes research participant members of Kasinthula Cane Growers Limited and the Chikwawa district who welcomed me into their community and offered significant time and effort to share their experiences, opinions, and concerns. It is from that information that all of this work has been built upon and would not have been possible otherwise. My gratitude extends to Jason Agar and associates of Kadale who kindly hosted me in Blantyre and provided priceless advice and support. Also thanks to the research assistants for their excellent work with me in the field and for their friendship. Funding for this research was provided by the Economic and Social Research Council (ESRC Studentship PTA-033-2006-00041). The selection of the case study, research proposal, and funding for research were secured through collaboration between Newcastle University and Traidcraft Plc. 


\section{Uneven and unequal people-centered development: the case of Fair Trade and Malawi sugar producers}

\section{Introduction}

Fair Trade has been central as part of an expanding movement to connect markets and consumers in the global north with commodity producers in the global south. It is one of a number of sustainable sourcing certifications to embed certain social and environmental criteria and guarantees into a range of consumer products. ${ }^{1}$ The producer certification and product labeling system "Fairtrade" is governed by Fairtrade Labeling Organizations International (FLO) and its members who, together with worldwide partners including the World Fair Trade Organization, share a set of core principles that guide their operations. The Fair Trade approach highlights perceived problems in trade such as exploitation, marginalization, and exclusion from benefits of global market participation. The approach promotes strategies such as fairer market access, equitable trading relations, empowerment, and transparency.

Fair Trade discourse and practice have an emphasis on people-centered development, with a focus on efforts to empower producers and their communities. This has been noted, for instance, by Nicholls and Opal $(2005$, p. 6) who identify one of the primary objectives of Fair Trade as being to "empower producers to develop their own businesses and wider communities." In Fair Trade practice the approach to empowerment consists of payment of a fair price and a strengthening of producer organizations (Ronchi 2002) through support from Fair Trade Organizations (FTOs) to help build capacities of producers and organizations.

Despite increased use of the terms community and empowerment in Fair Trade literature and marketing, to date there has been little work to understand their meaning

\footnotetext{
${ }^{1}$ Fair Trade, as used in this paper, refers to a broader trade justice and development movement pioneered by Fair Trade Organizations that incorporates a wider range of products, campaigning and awareness raising activities. Fairtrade is a certification and labelling system governed by FLO and FLO-Cert to certify products that carry the Fairtrade Mark.
} 
critically in the context of Fair Trade. Low-income producer groups are treated as conduits of community empowerment approaches and are generally assumed to be willing and able to share benefits of Fair Trade among producer members and a wider community. To contribute to a developing academic critique of such assumptions, this paper presents an analytical framework to explore contextual governance and institutional factors such as local hierarchies that influence social and political relations in producer communities. I argue that these factors shape sites of uneven and unequal producer communities, which result in some unintended consequences evidenced from diverse experiences following Fairtrade certification of a particular producer organization.

This research adds to a growing depth of knowledge and critique by studying lived experiences of Fair Trade. It references empirical material obtained from research of a Fairtrade certified sugar producer organization in Malawi, Kasinthula Cane Growers Limited (KCGL). ${ }^{2}$ The case study shows how and why context and institutions are important to understand different empowerment consequences for different producer community actors, and therefore why one approach does not fit all situations. The argument developed is that not all producers can, or want, to empower their communities though development investments.

To date both Malawi, a marginalized African country, and sugar, a more recent product category entrant to the Fair Trade arena, have received limited critical enquiry. ${ }^{3}$ Furthermore, by focusing on Fair Trade in an African context, this paper challenges many of the assumptions that shaped Fair Trade standards regarding producer groups that are rooted in co-operative struggles of Central and South America. Co-operation in East and Southern Africa has been shaped by a different colonial and post-colonial history, and therefore by different institutions and contexts necessitating different understanding of expectations.

The Malawi case study analyzed inequalities, hierarchies, dependencies, and intended and unintended Fairtrade outcomes to provide an opportunity to reflect on how Fair Trade can continue to learn and evolve to improve livelihoods of a wider population of producers. Insights were obtained through analysis of the experiences of all actors involved in the production of sugar cane in this case study (principally farmers and hired labor), examination

\footnotetext{
${ }^{2}$ Material from doctoral research funded by the ESRC and collaboration between (will be completed upon acceptance).

${ }^{3}$ In contrast to other commodities such as coffee, tea, cocoa, and bananas in a number of countries. For instance see the work of Bacon (2004), Dolan (2008), Murray et al. (2003), Ronchi (2002), Shreck (2005), Tallontire (2000), and Taylor et al. (2005).
} 
of the context in which they are embedded, and how Fairtrade "rules of the game" have been lived and interpreted. The research specifically focused on the following Fair Trade empowerment principles that are listed in the Charter of Fair Trade Principles and the Generic Fairtrade Standards for Small Producers' Organizations (FLO 2009a): (1) creating opportunities for economically disadvantaged producers; (2) practicing transparency and accountability; (3) capacity building toward developmental impacts; (4) paying fair prices; (5) promoting equality and non-discrimination; and (6) working to improve working conditions.

The paper is structured as follows. The first section presents approaches that have been developed to analyze governance and institutions in contemporary global commodity networks. This extends critical analysis to foreground factors that shape local governance structures, labor relations, and wealth distributions. This is followed by a presentation of methods employed in the study, leading to a summary of the research context and forms of governance and institutions and the introduction of Fair Trade into the production community researched. Relevant empirical material is presented and discussed in the next section, highlighting unintended consequences of exacerbating inequalities, dependencies, and over expectations in a producer community. This leads to reflections for Fair Trade peoplecentered development based on experiences from this case study versus expectations. The final section summarizes key findings and interpretations and discusses challenges for Fair Trade regarding community empowerment.

\section{Global and local production networks}

Social science researchers have sought to explain and analyze the impact of contemporary networks on agricultural sectors as production and marketing activities have become increasingly interconnected and dependent through globalization processes. Various approaches have been developed to explain contemporary trade governance and flows. The different approaches theorize and analyze power relations, value appropriation, and the influence of governance (control) and institutions within cross-border commodity chains or networks. As part of this, in the past two decades the Global Value Chain (GVC) framework has been employed by researchers to analyze a range of commodity chains including agricultural commodities (see for example Bedford et al. 2002; Daviron and Ponte 2005; Humphrey 2005; and Slob 2006). By identifying the coordinating nodes of governance as 
part of value chain analysis it is then possible to locate which actors appear to occupy the positions of greatest economic and political influence in a particular chain.

Such international value chain analyses tend to use the chain metaphor in analysis of production and distribution, thus often discussing commodity and value chains in linear terms. This can prove limiting as a framework for analysis as discussed further below. Economic geographers including Henderson et al. (2002), Coe and Hess (2007), and Coe et al. (2008a, 2008b) have instead increasingly utilized a network based approach to investigate the impacts of globalization on regional development and a tool to analyze retail and multinational company networks. By retaining a focus on value capture and power relations, but utilizing the concept of a network, a production network approach provides scope to analyze multiple forms of governance and institutions.

In arguing for an emphasis on the "network," Coe et al. (2008b), Henderson et al. (2002), Hughes (2001), Leslie and Reimer (1999), and Raynolds (2004) argue that a major weakness of the "chain" approach is its conceptualization of production and distribution processes as being essentially vertical and linear. In other words, focusing on international trade flows between different groups of actors. They suggest that rather than an emphasis on the linear and vertical, processes are better conceptualized as being highly complex networks that also incorporate non-linear, horizontal relations. The network-based approach therefore includes "horizontal" relations such as class, ethnicity, and gender that shape the operation of production networks both in and between different localities (Coe and Hess 2007, p. 8). This enables a research focus on local governance and relations in addition to global (vertical) relations.

Fair Trade aims to affect global (vertical) commodity production, trade, and marketing relations and those (horizontal) relations within local production communities. Adopting a network based-framework provides scope to explore rich local contextual analysis for interpretation of the impacts of Fairtrade certification in the context of local community empowerment. This moves Fair Trade analysis from a traditional focus on governance in vertical trade relations to incorporate analysis of horizontal governance to highlight inequalities between different social groups in a particular place. Such an approach has increasingly been adopted in recent value chains work, for instance, by Tallontire et al. (2011) who developed a framework that incorporates wider horizontal processes of governance. Elsewhere Neilson and Pritchard (2009) advocate a move away from linear frameworks that have limited ability to account for geographical complexity in analysis, and 
Bolwig et al. (2008) argued a need to integrate poverty into value chain analysis to pay attention to horizontal environments within which low-income rural populations are situated.

Moving from value chains to production networks, Hughes (2005) identifies the three conceptual categories of the Global Production Networks (GPN) framework, value, power and embeddedness, which have introduced more emphasis on spatiality for economic geography research. The GPN framework, employing the concept of embeddedness, places more emphasis on institutions, governance, and social context in commercial agreements and relations. A challenge is to apply this concept to understanding factors that shape uneven and unequal lived experiences of community empowerment.

To analyze different networks and places embedded in different economic, social, and political contexts, there has been recognition of the need to account for and examine the role of institutions in society (Amin 2001; Hudson 2005; Jessop 2001; MacLeod 2001; Martin 2003; Neilson and Pritchard 2009; Philo and Parr 2000). An analysis of institutions can move analysis from simplistic political economy generalizations to look at how economies and societies are constituted and embedded in different contexts and thus present a greater representation of the complexities of social life. North (1991) introduced institutions as "humanly devised constraints that structure political, economic, and social interaction...devised to create order and reduce uncertainty in exchange" (1991, p. 97). He argues that institutions include formal (written) arrangements and informal (unwritten) institutions such as culturally specific customs and codes of behavior. Extending this definition, institutional arrangements are the forms of contract or organization (such as firms, unions, or councils) that are established for particular transactions to lay the ground rules for economic cooperation or competition. The institutional environment is the broader set of political, social, and legal rules of the game within which people and organizations develop and implement specific institutional arrangements (Morrison et al. 2000).

In much of the early application of both GVC and GPN frameworks, consideration of labor relations and wealth distributions that shape relations and incomes within the institutional arrangement of the firm has so far been limited in many instances. With regard to firms, Coe et al. (2008b) state that too often firms are treated as generic entities or "black boxes," as aspatial "lead" firms. In reality firms are systems of power that contain power relationships, and so it should not be assumed that all firms will, or will be able to, react in the same way to changes in an institutional environment. A similar critique can be leveled at community empowerment approaches by questioning the ability of one group of actors (e.g., the FLO) to define the needs of producers and communities located in a variety of distant 
geographical contexts. The low-income producer groups that represent the institutional arrangements through which Fair Trade aims to deliver benefits to a producer community are often portrayed as homogenous entities. In reality these groups do not operate in a vacuum; they are communities and networks subject to vertical and horizontal relations and forces, embedded in different sets of relations, networks, and institutional environments.

To explore Fair Trade in the context of community empowerment it is useful to utilize a network approach that facilitates analysis of multiple forms of governance and institutions that will be different in different contexts. This paper presents analysis of lived experiences that suggests there are particular shortcomings evidenced from intended and unintended consequences since Fair Trade certification. For Fair Trade this is a useful reflection in order to check assumptions and needs of producers and communities located in different contexts with whom the movement works and aims to improve their circumstances, ultimately resulting in an improved application of Fair Trade.

\section{Researching Malawi, sugar, and Fair Trade}

The fieldwork methodology for this study was designed to reflect and explore some of the empowerment strategies of Fair Trade such as inclusion, participation, supporting voice of the marginalized, and transparency. In addition, a Fair Trade reference group consisting of representatives of FTOs was consulted to ascertain their definitions of empowerment from their experiences to obtain key indicators of empowerment.

The examination of the impact of Fair Trade's community empowerment goals assessed primary producers' abilities to participate in and influence discussions affecting their livelihoods and make decisions in the environments in which they are located; their ability at both individual and collective levels to improve the livelihoods of themselves and others; and an identification of the principal inhibiting factors to community empowerment.

Using a variety of methods, a broad group of in-country stakeholders were interviewed and consulted to collate a range of understandings, expectations, and experiences. The fieldwork was conducted over two visits to Malawi in 2007 and 2008. The first visit was designed as a scoping visit and pilot study to collect background data, establish key contacts, recruit research assistants, clarify definitions of community and producer for this research, and conduct pilot interviews to ascertain some initial experiences and interpretations of Fair Trade. Reflecting upon the initial data collection generated an 
understanding of some anticipated outcomes such as income increases, but, critically, unintended consequences began to emerge, as will be discussed in this paper.

The majority of research data was collected during the second visit by conducting numerous interviews and focus groups to obtain rich qualitative and quantitative empirical material. With the participation of research assistants, the research team completed 47 one-toone interviews with sugar farmers, 55 one-to-one interviews with sugar employees, 11 focus group discussions with committees, farmers, and employees, eight group discussions with villagers living in a sugar scheme community, interviews with members of the KCGL and the Illovo Sugar Malawi management teams, interviews with District Assembly representatives, and an interview with two employee members of Kasinthula's Fairtrade Social Premium (FSP) committee.

One-to-one interviews incorporated semi-structured questions that sought to understand (from sugar farmers and employees) community development and needs (social development), knowledge of Fair Trade, training received, participation in decision-making and Fair Trade relations (individual development), and snapshots of livelihoods circumstances and recent changes (economic development). Focus group discussions were organized as purposive group discussions with farmers, employees, and committees to expand on identified themes and issues from earlier interviews. Separate interviews were held with two employees who were members of the FSP committee upon their request after they stated an inability to express their voices in-group discussions. After collecting empirical material, the collated materials were analyzed and reviewed for key themes and categories to build interpretations.

Secondary data sources were consulted to identify forms of governance and institutions, including Fair Trade practices, sugar cane supply agreements, and chieftainship and customs. All of these institutional arrangements can contribute to variable impacts of community empowerment (Luiz 2009; Casson et al. 2010), and understanding more about them helps to get a better understanding of the impact of an embedded social and political context on efforts to empower a producer community.

\section{Embedded social, political, and economic context}

Contextual analysis for this study also identified a number of factors that have kept Malawi embedded in dependent international relations and large sections of the population embedded 
in a society containing knowledge asymmetries and power imbalances. This embeddedness limits opportunities for a majority to be able to enhance their lives through connections to global agricultural production networks directly. The continued dominance of Traditional Authority leaders in rural governance and remaining postcolonial dependence on external donors means there are large percentages of the population considered as subjects and not empowered citizens who are capable of bringing about change to their lives. ${ }^{4}$ As Pinder (2004) claims, this has maintained a long-running "hand-out" rather than "hand-up" culture in Malawian society.

As a result, a large majority of Malawians face constraints due to a combination of low levels of formal education, exposure to numerous severe health risks, a weak agricultural economy, and hierarchical trade and community relations. Furthermore, repeated economic, social, and climatic shocks have reduced assets, savings, and abilities to enhance livelihoods or to assist others (UNICEF 2006). This combination of factors and circumstances leaves a population that lacks some of the capacities, capabilities, and freedoms that are frequently stated as essential components of development and empowerment (DFID 1999; Sen 1999).

It is widely recognized that the global trading and production networks of sugar have been some of the most tightly regulated in international trade (DEFRA 2006; Richardson 2009). The governance of the international trade of sugar is highly political and subject to a variety of regulations, tariffs, quotas, and preferential multilateral agreements since the rise in demand for sugar and the new economic benefits coming with that demand over the past 150 years or more. During Malawi's post-independence era (1963-), the most significant arrangement for low-income countries such as Malawi has been the European Union (EU) "sugar regime," which remained virtually unchanged since its establishment in 1968 (DEFRA 2006). The sugar regime was based upon three pillars: guaranteed prices, export subsidies, and import restrictions (Richardson 2009). It was designed to support EU sugar beet growers with each member state allocated certain quotas. Non-EU sugar was subject to import tariffs to make EU sugar more competitive. Exceptions were made for former British and French colonies, collectively referred to as African Caribbean Pacific (ACP) countries. Following a ruling by the World Trade Organization that such preferential arrangements broke free trade

\footnotetext{
${ }^{4}$ Local government districts in Malawi are subdivided into Traditional Authorities governed by chiefs. In many ways traditional structures in rural society in Malawi exist in parallel with national and local government administrative structures. TA leaders, for instance, govern access to customary land and associated rights to cultivate on that land.
} 
rules, the EU introduced a new sugar regime, effective since 2007. As a result ACP sugar will be quota free and duty free and so there will be no further fixed prices or quotas for raw sugar exported from Malawi. ${ }^{5}$ The increase in politicization and regulation has significantly changed the governance and institutional environment of global sugar trade and production networks.

The agricultural sector in Malawi employs approximately $80 \%$ of the labor force and accounts for over $80 \%$ of export earnings. Tobacco is the leading cash crop export, accounting for approximately $60 \%$ of agricultural export earnings, followed by sugar and tea (NSO 2006). In the tea and sugar sectors small-scale production only accounts for approximately $5 \%$ of total volume of each commodity, with larger scale estates and plantations contributing the bulk of the total volume. ${ }^{6}$ The sugar sector has been dominated by estates since its introduction in 1965 .

The Illovo Sugar Group is Africa's largest sugar producer, producing approximately $40 \%$ of Southern African Development Community sugar (Illovo 2008). In Malawi, Illovo has two sugar mills and plantations, one in Dwangwa to the north of Lilongwe and another at Nchalo, south of Blantyre (see Figure 1). To increase the quantities of sugar cane available to the mills, Illovo participated with the government of Malawi to establish outgrower schemes where customary land is held in trust. In the south of Malawi a small-scale sugar cane growing company, Kasinthula Cane Growers Limited (KCGL), was established in the district of Chikwawa in 1996. A board of trustees for the Shire Valley Cane Growers Trust was established to be responsible for the formulation of policies regarding the management of the scheme. The land for the scheme was leased by the Government of Malawi to the Trust and subleased to the individual farmer members of the KCGL.

[Figure 1 about here]

The unique governance structure of KCGL incorporates a management team, 282 farmers, approximately 260 permanent employees (irrigators, security, herbicide sprayers, admin, and others), and approximately 250 seasonal laborers as cane cutters and harvesters. Those referred to as farmers were granted a sugar cane plot of between 2.5 and 3 hectares from which they receive a direct income. These landholders are members of local traditional

\footnotetext{
${ }^{5}$ Intended to be effective from October 2015.

${ }^{6}$ I. Parrott, personal communication 10 June 2008, and B. Namata, personal communication 27 September 2007.
} 
leaderships who dominate membership of committees and therefore have the direct links to outside actors such as Fair Trade personnel. This is in contrast to employees who are employed by KCGL to work in the fields but do not receive income from the plots of sugar cane. The farmers also manage the employees who work on their plots of sugar cane. Following the inception of the scheme, the membership of the Trust and the principal committee control positions within KCGL were secured by those locally empowered as members of the Traditional Authority hierarchy.

The growing and processing of sugar cane tends to be located in close proximity which is due in part to the necessity to process sugar cane soon after harvest to extract the optimum quantity of sugar from the raw material. Sugar fields are normally located close to a sugar mill and smaller-scale sugar producers are therefore often structurally dependent on a large mill to process and add value to their sugar cane. In southern Malawi sugar is collected daily during the harvest season for processing and marketing by Illovo from Kasinthula's sugar plots (700 hectares in 2008), located $20 \mathrm{~km}$ north of the Illovo mill and plantation $(12,000$ hectares $)$.

From the outset of the KCGL scheme, a Cane Supply Agreement (CSA) was signed that is in force for at least 25 years. In the CSA was an agreement that all sugar produced by KCGL would be sold to the Illovo mill at Nchalo. The pricing system for Kasinthula sugar is based on a "division of proceeds" (DOP) system that is designed to provide transparency in financial transactions between KCGL and Illovo. The DOP is structured as follows: from an average price obtained from all ex-mill sales of sugar and molasses realized by the Illovo mill, KCGL receives $60 \%$ of the revenue generated from the cane they supply to Illovo. As the refiner and marketer, Illovo retains $40 \%$ to cover various production and marketing costs, a common industry agreement.

\section{Fair Trade and KCGL}

The principle objective of Fair Trade is to improve the livelihoods of those participants in production networks who are seen to be most excluded from benefits of trade. Fair Trade aims to bring about change by affecting nodes of uneven governance, unfair wealth distributions, the capacities and capabilities of low-income producers, and promoting 
responsibilities for social development at all points in production networks (FLO 2009b) ${ }^{7}$ in different social, political, and economic contexts.

Kasinthula received Fairtrade certification status in 2002, a process partly driven by Illovo and the FLO's desires to get Fairtrade into the ACP sugar sector. Referring to Raynolds et al. (2007) and Fair Trade representatives interviewed for this study, the combination of this certification and relations with FTOs should benefit small-scale producers in the following ways: first, benefiting financially by paying guaranteed prices for commodities which are higher than the prevailing world market prices. Second, it benefits by providing a social premium to finance local community development projects and for investment in the small-scale producer organization. The third benefit is through support from FTOs (sometimes supported by commercial partners) that is over and above requirements of FLO certification standards, and provides information and training to enhance business and market awareness and production and marketing skills. Fourth, as a Fairtrade certified producer group it is subject to auditable standards of the FLO that are aimed at improving the social and environmental well-being of the group members and their surrounding community.

In the case of Kasinthula, the producer group does not receive a guaranteed price as there has not been one determined for sugar given the complexities of the global sugar market and associated quota systems. ${ }^{8}$ Instead, KCGL receives a price from Illovo determined by the DOP calculation introduced above. Additionally, KCGL receives a Fairtrade Social Premium (FSP) for quantities of sugar sold to Fairtrade markets. These funds are paid directly to a bank account controlled by the KCGL Fairtrade Premium Committee. In 2007 approximately one half of KCGL's sugar was sold through Fairtrade channels. The group also receives some additional support in the form of information and training from FTOs and collaborators.

The FLO standards for small-scale producer organizations contain elements to which KCGL and other groups are audited for compliance. The standards are composed of three elements. First, social development requirements include commitments to instill democratic structures, a transparent administration, opportunities for all members to participate, and no discrimination. Second, socioeconomic development refers to the use of the FSP. The FSP is a payment made to the producer organization for each unit of Fairtrade produce sold. The funds are intended for investment in the sustainable development of the organization and the

\footnotetext{
${ }^{7}$ There are other aims related to the environment that are not relevant to this study.

${ }^{8}$ Situation at the time of research, since under review by the FLO and FTOs.
} 
surrounding community. Third, labor conditions lay out requirements regarding working conditions and employment policy. With reference to International Labor Organization conventions, the requirements include freedom from discrimination, freedom of association and collective bargaining, and consideration of safe and healthy working conditions.

Through these mechanisms certain desired empowerment outcomes are expected for those directly involved in the Fairtrade certified producer group and the communities in which members live. At the same time Fair Trade comes into contact and potential conflict with an existing embedded institutional and governance context. The following section presents interpreted lived experiences from the Kasinthula case study that highlight how and why those experiences have been uneven and unequal. In this research two key themes emerged that stress the importance of understanding more about context and the institutional environment to enhance Fair Trade partnerships. First, by not fully acknowledging the power of existing hierarchies with decision making and local influence in the hands of a few, unintended consequences of deepening exclusions and inequalities were experienced by some Kasinthula producers since Fair Trade certification. Second, many producers voiced frustrations regarding the community development expectations associated with the FSP.

\section{Problematizing production communities: deepening exclusions and inequalities}

As discussed, Fair Trade aims to affect representation, transparency, democracy, inclusivity, and participation in producer organizations, in keeping with the language of community in people-centered approaches. By emphasizing such practices, it is hoped (and arguably assumed) that sites of unevenness and inequality are reduced through fairer producer group and producer community relations. However, such approaches are already filled with assumptions and expectations of producer organizations, their members, and communities who constitute the target beneficiaries. Evidence from research foregrounds a theme of deepening inequalities among different Kasinthula producers in terms of awareness and participation since Fairtrade certification.

When consulted to offer a definition or understanding of Fair Trade, interviews with seasonal employees (e.g., sugar cane cutters) highlighted a general lack of ability to offer a definition or any conception of Fair Trade due to their lack of involvement in the process. In contrast, over $90 \%$ of farmers interviewed were more easily able to provide a definition, albeit interpretations of Fair Trade as something to help farmers and provide money through 
social premiums rather than a long-term process of empowerment. Similar trends emerged from analysis of questions relating to knowledge of Fair Trade standards, training received, social premium definition and use, Fair Trade committee elections and consultations. Consistently over $75 \%$ (often $90 \%$ ) of farmers confirmed awareness and participation, whereas $25 \%$ or fewer (often towards $0 \%$ ) employees were able to offer any knowledge or participation regarding Fair Trade.

To illustrate a picture of difference, exclusion, and inequality, the following excerpts from interviews build on the data. Some farmers interviewed were clearly motivated to do more as a result of learning more about Fair Trade sales and good agricultural practice (GAP) techniques. One female farmer explained, "after attending some training I learnt more about food farming methods and how Fair Trade operates. I am now working harder than before to produce good sugar cane so that my returns and benefits from Fair Trade should increase." Spending time in a nearby village, it was clear that all of the KCGL farmers I met there were very involved in Fair Trade matters and receiving significant sums of money from FSP payments. From such responses it appears that for the majority of farmers interviewed there are strong connections to Fair Trade information processes and motivations generated by such connection. That connection materializes from occupying more senior positions in the Kasinthula producer hierarchy, particularly those farmers on the FSP and other committees.

Some farmers did state that they worked in the fields, but the majority said they did not, either due to age, status, or other occupation. Most of the work in the fields is carried out by permanent and seasonal labor employed by KCGL. Approximately one third of the active participants in the production of Kasinthula sugar cane are seasonal employees, many of whom do not live permanently in the local Chikwawa district. A number of these employees were interviewed at the employee camp where they live during the sugar cane harvest season that lasts approximately eight months. For those interviewed, this represented the first opportunity to learn about Fair Trade. For instance, one man who volunteered some time for interview after working all day cutting cane explained "we only know about Fair Trade because of your meeting yesterday, you are the first to tell us anything about Fair Trade. Before my friends and I had heard the term but did not know much about it." Exclusion from any knowledge of Fair Trade and subsequent benefits led him to complain about his personal and family's circumstances. A lack of knowledge regarding Fair Trade among producers has been acknowledged in earlier research (for example by Shreck 2005). What is particularly revealing in this case is the significantly lower level of knowledge among Kasinthula farm employees compared to farmers with land title to plots of sugar cane. 
The principal reasons offered by the seasonal employees interviewed regarding their lack of awareness and participation related to an exclusion from consultation about Fair Trade. As temporary residents and hired labor they considered themselves as separate from and of a lower status compared to the farmer members of Kasinthula who are embedded in the local society. Reflecting a sense of exclusion, in discussion with one man who earned the equivalent of US\$1.50 per day for cutting cane by hand, he said “we don’t know anything about Fair Trade because we are just seasonal employees." At the time of interview this man had worked for five seasons for Kasinthula. Despite that period of service, during which time KCGL received Fairtrade status, he continued to point out that "to us Fair Trade is just a song; we don't see its impact or any benefits where we live." As a temporary resident in the district his concerns principally related to the condition of housing and sanitation at the employee camp, which had received no investment in the years he had lived there. Others cited poor housing, limited clean water, and only one bathroom, an issue that was presented as being particularly uncomfortable for women.

Such variations reflect the different positions from where different KCGL producers are situated. The population of farmers occupying positions on committees and close links to local leaders are those in direct contact and receipt of information from external actors. Encountering sentiments of exclusion and frustration suggested a lack of dissemination and consultation with a landless population at Kasinthula by either KCGL personnel or previous external visitors to the scheme. These issues were explored in further interview conversations with reference to the principal mechanisms designed to improve fairness and livelihoods through Fair Trade at Kasinthula. Discussing this with representatives from a range of producers revealed a sense of "them and us," reflecting uneven levels of participation, control, and influence.

A feeling of exclusion and subsequent frustration at this situation was expressed when discussing the matter with a group of employees; "Fair Trade side-lines the workers. It is the worker who is looking after the crop in the field and therefore plays a crucial role in determining the yield at the end of the season." Such unintended consequences of deepening exclusions and inequalities in a Fairtrade certified production community are foregrounded by highlighting and analyzing variations in different producer levels of participation and benefit from Fairtrade practices and Fair Trade relations. Focusing on the influence of position and hierarchies showed how lived experiences of Fairtrade by those involved in sugar cane production vary depending on levels of entitlement to land, connections to indigenous leadership, and incomes. 
In the Fair Trade context, sometimes empowerment is referred to as a process resulting from payment of Fairtrade prices and provision of market information (Dolan 2008; Raynolds 2002). Others, for instance Mayoux (2001), introduce social and political empowerment at the levels of both individual producers and organizations. For this research a distinction was made between empowerment as a process of achieving economic impacts, such as improved incomes, and social and political impacts evidenced as improved levels of control and influence over matters affecting livelihoods. Experiences and attitudes regarding economic, social, and political empowerment elements of Fair Trade were explored with Kasinthula producers. This reinforced a theme of inequalities discussed above, and revealed a second theme of variable abilities and willingness to work with Fair Trade empowerment expectations.

After establishing an impression of income levels, research participants were asked whether they perceived an impact on their incomes since Fairtrade certification. In response nearly all (92\%) farmers stated a positive impact, whereas $72 \%$ of permanent employees stated there had been no impact. When asked whether participants have access to affordable financial credit, $55 \%$ of farmers said they had been accessing credit for some years and a further $20 \%$ were confident they would be able to access credit soon. In contrast, $40 \%$ of permanent employees have never had access to affordable credit, but $40 \%$ were hopeful of accessing it soon.

Those interviewed were asked to describe in more detail the impact of their individual financial situations on their abilities to provide for their families and enhance their livelihoods. General themes had emerged earlier of some participants receiving higher incomes and better access to credit than others. One man who had been employed for five years as a cane guard explained he had three others dependent on his income to meet basic nutrition and shelter needs. Discussing his ability to meet those needs he complained:

My income is not a fair return for my work. I also sell some of my own produce and offer labor to help meet my family's needs. As employees we are still crying with our low incomes. The money is not enough to do anything apart from buying necessities at home.

This is a situation that represents the experiences of many rural agricultural workers with limited power to affect their livelihoods. In the context of Fair Trade there is an expectation of improved incomes. When direct financial impacts are not apparent, tensions are evident as 
those unable to empower themselves through livelihood investments are envious of other producers whom they see benefitting from higher incomes and better opportunities to access loans. Therefore, uneven experiences of financial empowerment should be anticipated in an institutional environment comprising hierarchies determined by land ownership, local leadership structures, and subordinate culture.

In separate interviews, constituents of local production and development networks explored the issue of what principal factors inhibit those regarded as disempowered from becoming more empowered to take control and influence over their livelihoods. Representatives from Illovo, the KCGL management team, and local development consultants all cited low levels of literacy, limited capacities (skills and knowledge) to act, and local politics as significant barriers to choice and influence for the majority at Kasinthula to be empowered through Fair Trade. This point was summarized by a local nongovernmental organization worker:

Because of low literacy levels and local political structures, most people in rural Malawi are either not able or not informed to be able to make their own decisions. It is also impossible with an illiterate population to expect them to vote with knowledge of Fair Trade and related issues. Most people only vote for who they know or who talks the loudest. Poverty and democracy are a negative correlation.

Issues regarding low levels of formal education among farmers (many of whom are directly connected to local leadership structures) and limited capacities were voiced by management teams at KCGL and Illovo:

Fair trade people are expecting first world education and business sense from a villager with very little education. Right now low levels of formal education are the biggest barrier. There is too much expectation placed on people with very little education. There is a lot of complicated literature in English.

In Fair Trade and other people-centered development approaches, socioeconomic development is normally expected to occur through employment of technical approaches such as provision of social premiums towards investment in producer and community development projects. The most significant technical element of the FLO model in the context of sugar cane is the Fairtrade Social Premium (FSP) in the absence of a Fairtrade 
price for sugar. At the time of research the governance of significant levels of FSP funds in this case study was entrusted to a group of ten KCGL producers, originally all farmers who own title to plots of sugar cane. ${ }^{9}$ The locations of the distribution of wealth generated by FSP receipts depend upon the decisions of that committee. According to the rules of the FLO standards, distribution should include contributions towards community development.

Depending on individual circumstances, some farmers (especially those members of Traditional Authorities) felt more able than others to be socially responsible toward other villagers. In addition to ability, however, an intertwined issue of willingness emerged from the Traditional Authority leader of Chikwawa, who is also a Kasinthula farmer. When discussing the subject of Fair Trade, he complained:

Fairtrade standards restrict the use of money. Farmers are owners of the sugar but have to implement projects for the community who do not work on the cane, why? Farmers have their own needs and as owners of the cane that is sold why should they have to share money with employees?

One farmer who was also the Village Headman of a local village revealed an example of a combination of a lack of ability and willingness. When asked how he would use a relatively large sum of FSP money he stated, "like many farmers I am illiterate and cannot manage money well. Some farmers use the money irresponsibly but also many of us have emergencies such as when family members become sick." Livelihood shocks such as illness are very real and often such emergencies will require relatively large amounts of money. This reduces potential amounts that people are able or willing to set aside for wider community development use.

In interviews with members of the KCGL management team and at the Illovo Nchalo plant there was a sense that some Fair Trade principles regarding social responsibility were not understood and that to most farmers Fair Trade represented only more money coming to them from their sugar cane sales. One Illovo manager stated

Fair Trade compels producers to work with the community by complying with Fair Trade standards on social premium usage. Farmers ask, "Why are we doing this?" "Shouldn't it be the responsibility of the government to provide to citizens?"

\footnotetext{
${ }^{9}$ As indicated earlier in the paper, this was amended to invite two employees into the committee.
} 
Corporate social responsibility is something that many do not understand or do not regard as important because they have not had it in their lives before.

These examples foreground tensions and gaps between individual accumulation needs and expectations of communal values that are contained in social empowerment aspects of Fair Trade. Offering a reason for the gap between expected outcomes of Fair Trade and local interpretations, a representative of the local District Assembly suggested, "with Fair Trade the first thing is that cane growers need to understand the principles. The extra dividends are supposed to be for social responsibility but the farmers do not understand that." On a more sympathetic note, appreciating the general low-income status of Kasinthula producers, a Fair Trade informant questioned the social responsibility aspect of Fair Trade saying, "why should we expect the poor to be philanthropic? If they have needs to be met then surely they have the right to decide what to spend money on." This brings attention to the question of whether it is fair to expect those with individual (and family) needs to accept responsibility towards the needs and rights of others, particularly when people are exposed to frequent unexpected livelihood shocks such as illness. Furthermore, as introduced at the beginning of this paper, the levels of awareness and knowledge of the fundamentals of Fair Trade vary between different low-income producer groups located in different geographical contexts. Their attitudes depend upon their level of experiences and culture of principles central to the Fair Trade model, such as democracy and cooperation.

\section{Reflections for Fair Trade people-centered development}

Evidence from this research contributes toward a growing critical literature on realities of unintended consequences of increasing inequalities that has emerged from other case study research. For instance, Getz and Shreck (2006, p. 498) suggest "attention to the experience of certification at the level of production also reveals the unintended consequence that production for the Fair Trade market could actually exacerbate the socio-economic inequalities that exist locally." Likewise, Dolan (2010, p. 8) found evidence that "there is the potential to exacerbate rather than ameliorate the gap between the haves and have-nots." In the case of Kasinthula, the increase in inequality is particularly related to the (relative) elites getting wealthier and more influential than the poor necessarily getting poorer. 
Exposing issues concerning transparency and governance (control) of decision making in the hands of a minority at Kasinthula builds a critique of consequences regarding the Fairtrade approach and associated challenges. For instance, capture of control and benefits by those in relatively elite positions is a challenge facing movements such as Fair Trade that have democratic and equality ambitions embedded in its approach. Unintended consequences of "elite capture" are more likely to be witnessed when such approaches encounter instances where democratic ideals and practices are not embedded in the experiences of the majority population, as in the context in Malawi. ${ }^{10}$ In a situation such as that at Kasinthula, limited attention to embedded uneven social and political structures has resulted in the appearance of an influential minority in committees designed to empower a wider majority. ${ }^{11}$

In terms of notions of community, findings such as these challenge assumptions often made in people-centered interventions regarding cooperative, harmonious, and equal communities. Uneven levels of participation and awareness between those with title to land and the landless contradicts imaginations of equality embedded in people-centered community empowerment discourse (Lacey 2009). Writing about challenges to reduce assumptions of harmonious and co-operative producer communities, Berlan (2008, p. 173) notes how "academic literature on Fair Trade that has emerged in recent years has begun to question some of its marketing and underlying assumptions." Such literature generated by scholars including Arce (2009), Dolan (2008, 2010), Luetchford (2008), and Mendez (2002) supports arguments being made here about the need to reduce assumptions of homogenous harmonized groups of people. Instead there should be enhanced focus on local political economy issues such as social exclusion to marginalize unintended consequences such as increased inequalities between different producers. In support of this argument, Luetchford (2008, p. 165) highlights "the cultural and romantic association of peasant modes of production diverts attention away from obvious inequalities between parties with different interests and capacities."

A greater focus on the uneven social and political institutional environment in this case has generated an enhanced appreciation of the nuanced circumstances (such as elite

${ }^{10}$ In their research Eberhart (2006) and Prieto et al. (2004) warn of a risk of producing "islands of prosperity" where only a limited minority (elite) capture benefits from Fair Trade in low-income communities.

${ }^{11}$ An issue also discussed by Hickey and Mohan (2004) and Luttrell et al. (2007). 
capture) that shape how Fair Trade is experienced in different ways by different producer group members when Fairtrade people-centered rules enter such a context.

While it would be unfair to suggest that Fair Trade should be able to meet the needs of all producers, it is important to highlight unequal experiences to demonstrate the important role of environment that shapes uneven levels of awareness, participation, and benefit. Analyzing asymmetries in knowledge obtained, participation in Fair Trade processes, and in subsequent financial and human capital benefits among different producer members at Kasinthula has revealed a widening of influence and wealth gaps between and among producers. Only a small number of relatively elite farmers in this producer community control and influence decision making and wealth distributions due to the positions they hold, and the entry of Fair Trade processes have reinforced that status.

In reality, Fair Trade actors have imperfect information and knowledge about the producers and communities that represent those seen to be in need of empowerment. In this situation Fairtrade can be critiqued for some of the shortcomings leveled at other peoplecentered development programs. While well intentioned, problematization of assumptions embedded within implementation of the Fairtrade producer community concept highlights unintended consequences such as exacerbation of sites of exclusion and discrimination, particularly on the part of hired labor.

Focusing on the FSP brings into question the ability or willingness of low-income producers to accept rules on sharing proceeds from sugar production. Social premiums intended for community development projects have been interpreted as a "social tax" on those with competing priorities and facing livelihood shocks. It was often stated that individual needs come first before the "luxury" of social responsibility. The situation contributes to arguments being developed in critical literature of Fair Trade that discusses the constraining effects of landlessness and socio-cultural inequalities that affect access to resources and political participation in order to be able to use Fair Trade as a tool for empowerment (Dolan 2008; Luetchford 2008).

This critique echoes messages emanating from analysis of producer responses in the Kasinthula case and other recent Fair Trade studies focusing on this aspect. Perspectives of frustration and resentment further an argument to challenge assumptions of community and contribute to emerging debates regarding tensions between individual needs and selfinterests, and expectations of willing "common good" responses by members of Fairtrade certified groups to meet some local community needs (Dolan 2008; Jaffee 2007; Murray et al. 2006; Ruben et al. 2009). 
Analysis of this case study develops an argument that producer empowerment is a luxury on the basis that many producers are often unable and unwilling to deliver empowerment expectations associated with Fair Trade. This argument is in two parts, first there is a need to check expectations of empowerment when many low-income producers are faced with financial, social, and political constraints. Empowerment expectations, in particular social responsibility aspects associated with use of the FSP, are generated through the rules of the FLO and images created through Fair Trade discourse. In situations such as the one encountered in this study, responsibility to contribute towards local community development projects is a luxury many cannot or will not afford.

Second, there is a need to consider expectations by accounting for the positions from which different low income producers are starting. For Fair Trade to "succeed" in empowering others, there is a prerequisite that low-income producer partners are endowed with certain "ingredients" as skills, knowledges, capabilities, and a history of co-operation to be able to benefit more fully from Fair Trade. When such ingredients are lacking, a group of producers may not embrace principles expected with Fair Trade such as democracy, transparency, equity, and social responsibility. Instead, a series of uneven and unequal experiences and interpretations emerge. This supports a developing critique of assuming harmonious producer communities, instead foregrounding tensions and resentments.

Incorporating analysis of an unequal and uneven producer community shows that those expressing empowerment as improved livelihoods are producers in the most significant sites of governance (those producers with title to plots of sugar cane land, Traditional Authority leaders, and direct relations with the FLO and FTOs). Those not holding such positions have been unable to participate or benefit. Such findings suggest a need for further interrogation of community assumptions in Fair Trade to better target local inequalities in empowerment approaches.

\section{Conclusions}

This paper has explored lived experiences of a Fairtrade certified producer group and highlighted a series of uneven and unequal experiences as unintended consequences since certification. The influence of context on experiences of Fairtrade for different producers is aided by examination of a local institutional environment embedded with unequal social, political, and economic circumstances. In this study the term producer has been unpacked to 
highlight different producers who are otherwise often referred to as one entity. Producers include farmers, managers, and hired labor, all of whom have different situations and positionalities that affect how participation in and benefits from Fairtrade are shaped.

At both individual and group levels, there was clear evidence of some producer empowerment impacts as envisioned through Fairtrade. For instance, many farmer members of KCGL in particular mentioned improved financial power as a result of improved incomes and credit access as loans from KCGL since Fairtrade certification. Also the profile of Kasinthula has been enhanced internationally as a sugar cane scheme that is producing good quality produce, reaching global markets, and having advanced relations with the nearby sugar estate owned by Illovo.

However, the principal focus of this paper has been on the uneven and unequal experiences among different producer members of Kasinthula. Exploring the concept of a producer community, in particular the influence of position and hierarchies, shows how lived experiences of Fair Trade by those involved in sugar cane production varies depending on levels of entitlement to land, connections to indigenous leadership, and incomes. The evidence suggests an influential role of uneven forms of local governance and labor relations in shaping Fair Trade knowledge and experience. This supports an argument regarding the role of social relations of production in affecting who benefits and participates, also discussed by Cumbers et al. (2008) and Luetchford (2008). As the FLO standards are designed to inform and improve livelihoods, a first stage would be to ensure the intended beneficiaries are aware of them and their purpose. The evidence in this study suggests a shortcoming in ensuring that first criterion was achieved, and suggests a need for further interrogation of community assumptions in Fair Trade to better target horizontal inequalities in empowerment approaches. This is achieved in a network-based approach by incorporating analysis of social, political, and economic inequalities between different members of a producer group in a particular place.

The most significant technical element of the FLO model in the context of sugar cane is the Fairtrade Social Premium (FSP) in the absence of a Fairtrade price for sugar. There were numerous sites of tension between individual wants or needs and community benefits in the context of a heterogeneous group of producers and local community. One site of tension was on the part of many employees of KCGL who saw farmers benefiting from receipt of significant portions of FSP money, while their salaries and benefits remained largely unaffected. A second tension regarded a wider community of residents living in villages occupied by Kasinthula members who, despite seeing some project investment (such as 
boreholes), reported the majority of funds going to relatively few individuals. These participant perspectives of frustration and resentment further an argument to challenge assumptions of community and contribute to debates and future research regarding tensions between individual needs and self-interests, as well as expectations to sacrifice some personal gain to be willing to invest in local community needs.

Imaginations and representations of cooperative producer communities who are willing and able to work with others, as often presented and assumed in Fair Trade discourse, are questioned by reflecting on such tensions. Some individual examples of ability or willingness to assist others did emerge from participant perspectives, but overall more instances of inability or unwillingness were presented, including interpretations of the FSP as a social tax. This process creates research space to re-think what can be delivered in terms of social and economic development through a Fair Trade community empowerment approach. In particular there is a need to further explore approaches that can more fully capture empowerment needs of different producers who have different capacities and positions in a specific local community environment.

As Fair Trade moves into more commodities and countries it will encounter more forms of small-scale producer group structures and relations. Foregrounding various forms of vertical and horizontal relations in a production network and analysis of multiple low income producer perspectives reveals a more contextualized understanding of differences between experience and expectation. This is important as Fairtrade standards and processes come into contact with an increasing number of different specificities of commodity and place contexts. For this study the process has presented a more complex situation that helps to explain how and why Fair Trade is experienced and understood in contrasting ways by different people involved in sugar cane production at Kasinthula.

Such critique adds to calls for Fair Trade approaches to be more attentive to placebased specificities such as local social and political strata. Sites of production are complex places, not immune to social stratifications or inequalities. This suggests lessons for the future that Fairtrade certification processes, in particular, can learn from. Principally these relate to revising assumptions of producers in terms of communities through:

- Exploring notions of producer and community;

- Increasing consideration of different starting positions of different producer groups and their members; 
- Re-thinking rules and expectations associated with use of Fairtrade benefits such as the FSP.

Meeting these challenges requires increased involvement of producer community members (landowners and non-landowners) in establishing fairer trade relations and rules of the game. More broadly it demonstrates that challenging imagined notions of community can advance critical debate regarding efforts to empower others and provides a framework for analysis of unique global and local institutional environments that shape experiences of people-centered development in different ways for different people.

\section{References}

Amin, A. 2001. Moving on: institutionalism in economic geography. Environment and Planning A 33: 1237-1241.

Arce, A. 2009. Living in times of solidarity: Fair Trade and the fractured life worlds of Guatemalan coffee farmers. Journal of International Development 21(7): 1031-1041.

Bacon, C. 2004. Confronting the coffee crisis: can Fair Trade, organic, and specialty coffees reduce small-scale farmer vulnerability in northern Nicaragua? World Development 33(3): 497-511.

Bedford, A., M.E. Blowfield, D.G. Burnett, P. and Greenhalgh. 2002. Value chains: lessons from the cocoa and tea sectors. Greenwich: NRI

Berlan, A. 2008. Making or marketing a difference? An anthropological examination of Fair Trade cocoa from Ghana. Research in Economic Anthropology 28: 171-194.

Bolwig, S., S. Ponte, and A. du Toit. 2008. Integrating poverty, gender, and environmental concerns into value chain analysis. Copenhagen: Danish Institute for International Studies, DIIS Working Paper no. 2008/16.

Casson, M.C., M.D. Giusta, and U.S. Kambhampati. 2010. Formal and informal institutions and development. World Development 38(2): 137-141.

Coe, N., and M. Hess. 2007. Global production networks: challenges and debates. GPERG workshop University of Manchester, 25-26 January 2007.

http://www.sed.manchester.ac.uk/geography/research/gpe/downloads/

Manchester_Jan07_positionpaper_final.pdf. Accessed 11 February 2009.

Coe, N.M., P. Dicken, and M. Hess. 2008a. Global production networks-debates and challenges. Journal of Economic Geography 8: 267-269. 
Coe, N.M., P. Dicken, and M. Hess. 2008b. Global production networks: realizing the potential. Journal of Economic Geography 8: 271-295.

Cumbers, A., C. Nativel, and P. Routledge. 2008. Labor agency and union positionalities in global production networks. Journal of Economic Geography 8: 369-387.

Daviron, B., and S. Ponte. 2005. The coffee paradox. London: Zed Books Ltd.

DEFRA. 2006. Reform of the EU sugar regime. London: DEFRA

DFID 1999. Sustainable livelihoods guidance sheets.

http://training.itcilo.it/decentwork/staffconf2002/presentations/SLA\%20Guidance\%20 notes\%20Section\%202.pdf. Accessed 17 July 2007.

Dolan, C. 2010. Virtual moralities: the mainstreaming of Fairtrade in Kenya tea fields. Geoforum 41(1): 33-43.

Dolan, C. 2008. In the mists of development: Fairtrade in Kenyan tea fields. Globalizations 5(2): 305-318.

Eberhart, N. 2006. Summary of the Fair Trade impact study concerning small farming organizations and families and their lands in the Yungas coffee region, Bolivia. Lyon: AVSF

FLO. 2009a. A charter of Fair Trade principles. http://www.fairtrade. net/fileadmin/user_upload/content/2009/about_us/documents/Fair_Trade_Charter.pdf. Accessed 15 September 2009.

FLO. 2009b. Generic Fairtrade standards for small producers' organizations.

http://www.fairtrade.net/fileadmin/user_upload/content/2009 /standards/documents/Aug09_EN_SPO_Standards.pdf. Accessed 15 September 2009.

Getz, C., and A. Shreck. 2006. What organic and Fair Trade labels do not tell us: towards a place-based understanding of certification. International Journal of Consumer Studies 30(5): 490-501.

Henderson, J., P. Dicken, M. Hess, N. Coe, and H.W.-c Yeung. 2002. Global production networks and the analysis of economic development. Review of International Political Economy 9(3): 436-464.

Hickey, S., and G. Mohan. 2004. Participation: from tyranny to transformation? Exploring new approaches to participation in development. London: Zed.

Hudson, R. 2005. Economic geographies: circuits, flows and spaces. London and Thousand Oaks, CA: SAGE Publications.

Hughes, A. 2005. Geographies of exchange and circulation: alternative trading spaces. Progress in Human Geography 29(4): 496-504. 
Hughes, A. 2001. Global commodity networks, ethical trade and governmentality: organizing business responsibility in the Kenyan cut flower industry. Transactions of the Institute of British Geographers 26(4): 390-406.

Humphrey, J. 2005. Shaping value chains for development: global value chains in agribusiness. Frankfurt: GTZ

Illovo. 2008. World of sugar 2008. http://www.illovosugar.com/ World_of_sugar/WorldSugarPricesandUpdates.aspx. Accessed 23 March 2009.

Jaffee, D. 2007. Brewing justice. Berkeley and Los Angeles: University of California Press.

Jessop, B. 2001. Institutional re(turns) and the strategic-relational approach. Environment and Planning A 33: 1213-1235.

Lacey, S. 2009. Beyond a fair price: the co-operative movement and Fair Trade. Manchester: Co-operative College, Paper 14.

Leslie, D., and S. Reimer. 1999. Spatializing commodity chains. Progress in Human Geography 23(3): 401-420.

Luetchford, P. 2008. The hands that pick fair trade coffee: beyond the charms of the family farm. Research in Economic Anthropology 28: 143-169.

Luiz, J. M. 2009. Institutions and economic performance: implications for African development. Journal of International Development 21: 58-75.

Luttrell, C., S. Quiroz, C. Scrutton, and K. Bird. 2007. Understanding and operationalizing empowerment. Berne \& London: SDC \& ODI

MacLeod, G. 2001. Beyond soft institutionalism: accumulation, regulation, and their geographical fixes. Environment and Planning A 33: 1145-1167.

Martin, R. 2003. Institutional approaches in economic geography. In A companion to economic geography, ed. E. Sheppard and T. Barnes, p. 77-94. Oxford: Blackwell Publishers.

Mayoux, L. 2001. Impact assessment of Fair Trade and ethical enterprise development. EDIAIS paper. http://www.sed.man.ac.uk/research/iarc/ediais/pdf/IAofFairTrade.pdf. Accessed 1 December 2005.

Mendez, V.E. 2002. Fair Trade networks in two coffee cooperatives of western El Salvador. Fort Collins: Colorado State University.

Morrison, J., A. Dorward, J. Kydd, C. Poulton, and L. Smith. 2000. Sustainable livelihoods and new institutional economics. http://www.liveli hoods.org/PIP/pip/nieint.html. Accessed 24 July 2007 
Murray, D.L., L.T. Raynolds, and P.L. Taylor. 2006. The future of Fair Trade coffee: dilemmas facing Latin America's small-scale producers. Development in Practice 16(2): 179-192.

Murray, D.L., L.T. Raynolds, and P.L. Taylor. 2003. One cup at a time: poverty alleviation and Fair Trade coffee in Latin America. Fort Collins: Colorado State University.

Neilson, J., and B. Pritchard. 2009. Value chain struggles: institutions and governance in the plantation districts of South India. Chichester, West Sussex, England, and Malden, MA: Wiley-Blackwell.

Nicholls, A., and C. Opal. 2005. Fair Trade: market-driven ethical consumption. London: Sage.

North, D. 1991. Institutions. Journal of Economic Perspectives 5(1): 97-112.

NSO. 2006. Malawi international merchandise trade statistics http://www.nso.malawi.net/data_on_line/economics/Trade\%20on\%20NSO\%20websit e/Trade_Index.html. Accessed 4 March 2009.

Philo, C., and H. Parr. 2000. Institutional geographies: introductory remarks. Geoforum 31: $513-521$.

Pinder, C. 2004. Economic pathways for Malawi’s rural households. London: CARE Malawi

Prieto, M., C. Seeley, and D.F. Murphy. 2004. Supply chain codes of conduct and Fair Trade initiatives. Chapter 13, Trade and gender: opportunities and challenges for developing countries. New York: United Nations.

Raynolds, L.T. 2004. The globalization of organic agro-food networks. World Development 32(5): 725-743.

Raynolds, L.T. 2002. Poverty alleviation through participation in Fair Trade coffee networks: existing research and critical issues. Background paper prepared for project funded by the Community and Resource Development Program, The Ford Foundation, New York.

Raynolds, L.T., D. Murray, and J. Wilkinson. 2007. Fair Trade. London and New York: Routledge.

Richardson, B. 2009. Restructuring the EU-ACP sugar regime: out of the strong there came forth sweetness. Review of International Political Economy iFirst: 1-25.

Ronchi, L. 2002. The impact of Fair Trade on producers and their organizations. University of Sussex, PRUS working paper no.11.

Ruben, R., R. Fort, and G. Zúñiga-Arias. 2009. Measuring the impact of fair trade on development. Development in Practice, 19(6), 777-788. 
Sen, A.K. 1999. Development as freedom. New York: Knopf.

Shreck, A. 2005. Resistance, redistribution, and power in the Fair Trade banana initiative. Agriculture and Human Values 22: 17-29.

Slob, B. 2006. A fair share for smallholders: a value chain analysis of the coffee sector. Amsterdam: SOMO

Smith, S., and S. Barrientos. 2005. Fair Trade and ethical trade: are there moves towards convergence? Sustainable Development 13: 190-198.

Tallontire, A. 2000. Partnerships in fair trade: reflections from a case study of Cafedirect. Development in Practice 10(2): 166-177.

Tallontire, A. 2009. Top heavy? Governance issues and policy decisions for the fair trade movement. Journal of International Development 21(7): 1004-1014.

Tallontire, A.M., M. Opondo, V. Nelson, and A. Martin. 2011. Beyond the vertical? Using value chains and governance as a framework to analyze private standards initiatives in agri-food chains. Agriculture and Human Values 28: 427-441.

Taylor, P.L., D. Murray, and L.T. Raynolds. 2005. Keeping trade fair: governance challenges in the Fair Trade coffee initiative. Sustainable Development 13: 199-208.

UNICEF. 2006. The Malawi social cash transfer pilot scheme, preliminary lessons learned. http://www.unicef.org/policyanalysis/files/The

Malawi_Social_Cash_Transfer_Pilot_Scheme_Preliminary_Lessons_Learned.pdf. Accessed 2 May 2008. 


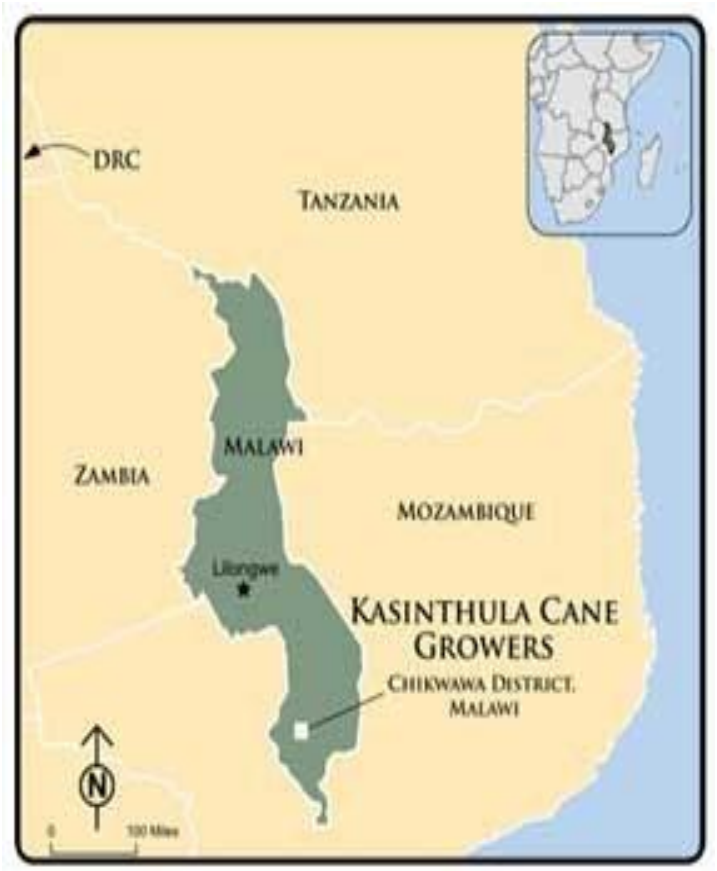

Figure 1. Map of Malawi and Kasinthula

Source: http://www.communityfoodenterprise.org/case-studies/international/kasinthula-canegrowers-limited 